\title{
Optimization of Cultural Conditions for Solid State Fermentation of Amylase Production by Aspergillus species
}

\author{
Bina Gautam ${ }^{1}$, Tika B. Karki ${ }^{2}$ and Om Prakash Panta ${ }^{1}$ \\ ${ }^{1}$ National College, Khusibu, Nayabazaar, Kathmandu \\ ${ }^{2}$ Department of Biotechnology, Kathmandu University, Dhulikhel \\ e-mail: busy.aug13@gmail.com
}

\begin{abstract}
Amylase is an amylolytic enzyme used in food industry which is generally produced by Aspergillus spp. under solid state fermentation. The present study is concerned with the isolation, screening and selection of suitable strains of Aspergillus spp. and optimization of cultural conditions for the biosynthesis of amylase. Rice and wheat brans were used as substrates which are readily available inexpensive raw materials for amylase production. From 85 samples of rice and wheat grains, 55 colonies obtained on potato dextrose agar (PDA) were suspected to be Aspergillus oryzae and only 35 colonies possessed the morphological characteristics similar to that of $A$. oryzae indicating the isolates were most likely the strains of A. oryzae. Of all the fungal isolates of Aspergillus spps., Asp.31 gave maximum production of amylase (720.782 IUgds $\left.{ }^{-1}\right)$ in solid state fermentation media. This strain was selected as a parental strain for optimization for cultural conditions. The obtained data were analyzed using SPSS11.5 program. Of all the substrates (rice bran, wheat bran and their mixture), rice bran was the best for producing amylase of highest activity $611.614 \mathrm{IUgds}^{-1}$. The highest enzyme activity of $698.749 \mathrm{IUgds}^{-1}$ was observed at $50 \%$ initial moisture level of the substrate. The optimum temperature was $25^{\circ} \mathrm{C}$ for producing the crude amylase enzyme with amylase activity of 577.757 IUgds $^{-1}$.
\end{abstract}

Key words: amylase activity, Aspergillus spp., crude amylase enzyme, solid state fermentation

\section{Introduction}

Amylolytic enzymes are those enzymes, which catalyze the hydrolysis of alpha 1,4 and/ or alpha 1,6 linkages in starch and related compounds. They act by hydrolyzing bonds between adjacent glucose units, yielding products characteristic of the particular enzyme involved (Teka 2006). The microbial amylases meet industrial demands with a large number of them available commercially and have almost completely replaced chemical hydrolysis of starch in starch processing industry (Patel et al. 2005). Solid state fermentation (SSF) constitutes an interesting alternative to most popular Submerged State Fermentation since the metabolites so produced are concentrated and purification procedures are less costly (Ellaiah et al. 2002).
Among a large number of non-pathogenic microorganisms capable of producing useful enzymes, Aspergilli are particularly interesting due to their easy cultivation, and high production of extracellular enzymes with potential industrial exploitation (Morya \& Yadav 2009). Aspergillus oryzae has an efficient system for secretion of proteins and is extensively used to produce industrial enzymes (Sivaramakrishnan et al. 2007). A. oryzae has received increased attention as a favorable host for the production of heterologous proteins because of its ability to secrete a vast amount of high value proteins and industrial enzymes, e.g. áamylase (de Souza \& de Oliveira 2010). Fungi are commonly used in SSF, due to their relatively high tolerance to low water activities, their high potential to excrete hydrolytic enzymes and their morphology (Rahardjo, 2005). 
Brans milled from cereal grains are particularly rich in dietary fiber and essential fatty acids and contain significant quantities of starch, protein, vitamins and dietary minerals (Wikipedia, 2011). Food and agricultural wastes can serve as substrates for the production of various fermented products and enzymes (Singh et al. 2009).

\section{Methodology \\ Sample collection}

Samples of rice and wheat grains were collected from different places of Kathmandu valley, Pokhara, Biratnagar, Dolakha, Syangja and Chitwan. Rice and wheat brans were collected from Kathmandu valley.

\section{Mold flora isolation}

Samples of rice and wheat grains that were assumed to be contaminated with A. oryzae were collected. The International Seed Testing Association Techniques (ISTA) especially (Agar plate method) was used to detect $A$. oryzae (Elbashiti et al., 2010). Each sample kernels were surface disinfected with $2 \%$ sodium hypochlorite $(\mathrm{NaOCl})$ solution and washed with distilled water for 3 times. Subsequently, the seeds were aseptically dried on sterile blotting paper and plated on PDA medium in order to isolate the associated mycoflora. The plates were incubated at $30^{\circ} \mathrm{C}$ for 7 days. After seven days, the developing fungal colonies were isolated. Isolated spores (assumed to be A. oryzae) were identified through macroscopic and microscopic observations and sub-cultured on PDA medium to obtain pure cultures of the isolates and maintained on PDA slants for further identification, incubated at $30^{\circ} \mathrm{C}$ for 7 days and stored at $4^{\circ} \mathrm{C}$ and sub cultured fortnightly (Maharjan, 2009).

\section{Identification of $A$. oryzae}

The isolates were inoculated on CYA(Czapex Yeast Agar) medium and incubated at $30^{\circ} \mathrm{C}$ for 7 days. CYA was prepared by adding yeast extract in CDA. After incubation period, all the plates were observed for macroscopic characteristics such as colony diameter, colony color, colony reverse, colony texture, and nature of spores (Elbashiti et al. 2010).

The microscopic characteristics were observed by preparing slides by Cellophane Tape Method (Aneja 2008).

\section{Screening of non-toxigenic Aspergillus spp. on Aspergillus differential medium}

Aspergillus differential medium (ADM) was used to identify aflatoxin producing and non-producing strains of A. oryzae. An inoculating needle was sterilized and point inoculation was performed on ADM. Inoculated ADM plates were incubated at $30^{\circ} \mathrm{C}$ for $48 \mathrm{hrs}$ and observed for development of bright yellow orange pigments (Bothast \& Fennell, 1974, Salkin \& Jordon, 1975).

\section{Screening of potent amylolytic mycoflora}

Preliminary screening for amylase production from Aspergillus isolates were carried out by Starch Agar (SA) plate assay (Morya \& Yadav 2009). The final constituents of media was $2.0 \mathrm{~g}$ soluble starch, $5.0 \mathrm{~g}$ peptone, $3 \mathrm{~g}$ beef extract and $15.0 \mathrm{~g}$ agar dissolved in 1.0 liter distilled water, warmed and autoclaved at $121^{\circ} \mathrm{C}$ for 15 minutes (Hi-media). SA media plate was point

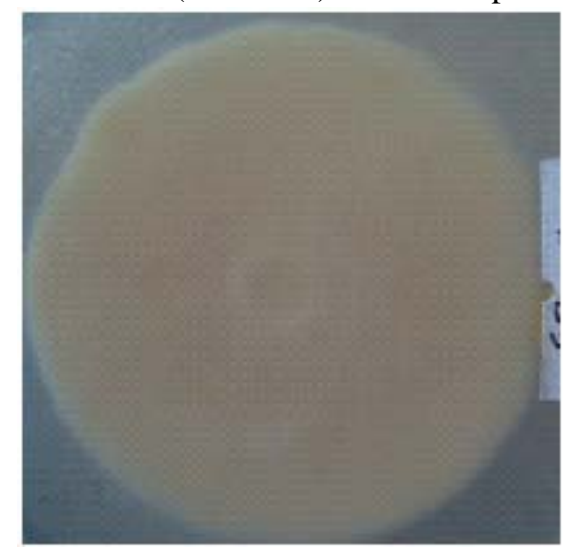

Fig. 1. Colony reverse of Aspergillus spp. Isolated from rice grain

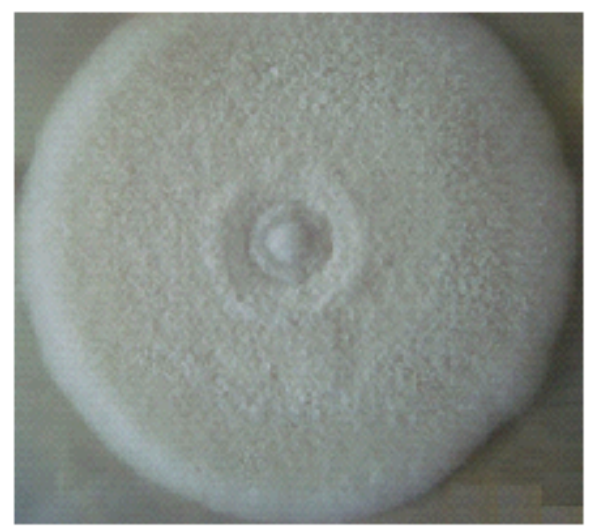

Fig. 2. Colony surface of Aspergillus spp. isolated from rice grain 


\section{Microscopic characteristics}

The microscopic characteristics of the isolates as observed were compared with identification key for A. oryzae and were found to comply with the given characteristics.

Conidial head- radiate to loosly columnar; Conidiophore- Relatively thin walls, definitely roughened throughout all or most of their length; Vesicle- Subspherical, less commonly flasked shaped, sterigmata covering the entire surface or upper three fourth; Conidiogenous Cell- Uniseriate and biseriate; Metulae or phialides covering the entire surface or the upper three-fourth of the vesicle; Conidia- (Sub) spherical to ovoidal, smooth walled to roughened Hyphae- Septate.

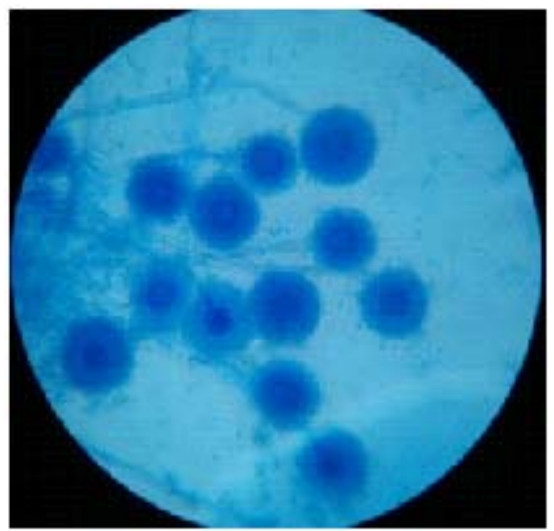

Fig. 3. Microscopic feature of Aspergillus spp. isolated from rice grains

\section{Screening of A. oryzae}

Isolates were grown on ADM to screen non-toxigenic strain. The development of bright yellow orange colonies indicates toxigenic strain whereas absence of bright yellow orange pigmentation indicates the strain to be non toxigenic. Similarly amylolytic activity of isolates was determined by performing starch hydrolysis test on SA plates and the zone of hydrolysis formed by each isolates were compared. Strains which showed maximum zone of starch hydrolysis were selected for enzyme production.

\section{Selection of fungal strains for enzyme production}

All the isolates suspected to be $A$. oryzae were compared and three strains with high amylolytic activity were selected for enzyme production. Three isolates of Aspergillus spp. Asp.19, Asp.14 and Asp.31 with zone of hydrolysis of $1.3,1.5$ and $1.3 \mathrm{~cm}$ respectively were selected.

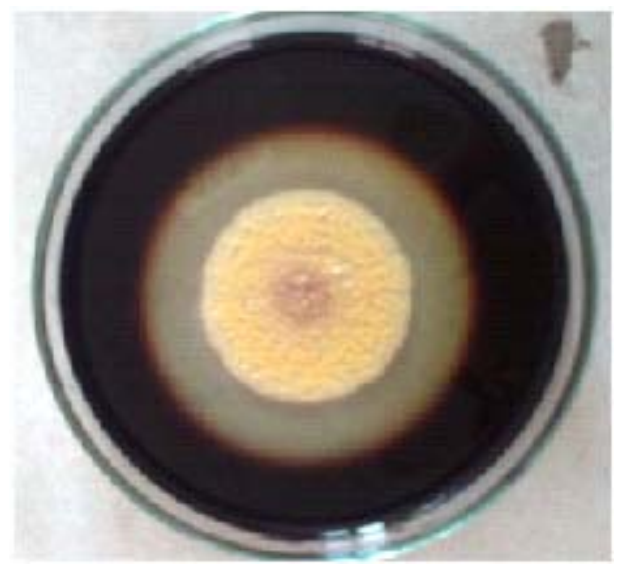

Fig. 4. Zone of hydrolysis on starch agar

\section{Solid state fermentation}

On the basis of cultural and morphological characteristics the isolate Asp.19, Asp.14, Asp.31 and Asp.33 were found to belong to the genus Aspergillus and closely related to the species A.oryzae while compared to standard description. SSF was adopted for enzyme production using rice bran, wheat bran and their mixture as substrate, employing three strains of Aspergillus, Asp.19, Asp.14 and Asp.31 and fermentation was carried out at different temperature $\left(25^{\circ} \mathrm{C}, 30^{\circ} \mathrm{C}\right.$ and $\left.40^{\circ} \mathrm{C}\right)$ and different moisture content of substrate $(50 \%, 60 \%$ and $70 \%)$ maintaining initial $\mathrm{pH}$ of substrate between 6-7.

\section{Determination of enzyme activity}

Different culture conditions greatly affect on the production of amylase (Cherry et al. 2004). Farid and Shata 2011 reported that the enzyme production was affected by strain type, incubation periods, and level of moisture content and carbon source supplementation. Laboratory experiment was carried out to optimize culture conditions for enzyme production by fungal isolates.

Enzyme activity was determined for these different strains in different substrate with different moisture content at different temperature. All the experiments for different studies explained below in figure and text were carried out in triplicates and values were averaged. One unit (IU) of amylase is defined as the number of 
micromoles of reducing sugars (glucose equivalent) released per 10 minutes by the total amount of enzyme under the assay conditions and enzyme activity is expressed in terms of IU per gram dry fermented substrate (IU gds ${ }^{-1}$ ). Weight of dry fermented substrate is determined by drying fermented residue obtained after filtration of crude enzyme extract in hot air oven at $80^{\circ} \mathrm{C}$ for $16 \mathrm{hrs}$ and weighing the dry fermented substrate without filter paper.

\section{Effect of substrate on enzyme production}

Three kinds of substrate rice bran (RB), wheat bran (WB) and mixture of rice and wheat bran (RB_WB) were inoculated with isolated strain Asp.14 and incubated at $30^{\circ} \mathrm{C}$ with initial moisture content of $60 \%$ and $\mathrm{pH}$ of substrate between 6 to 7 for 120 hrs. The crude enzymes extracted from fermented mash were assayed for amylase by DNS method. The result obtained is depicted below in Fig. 5.

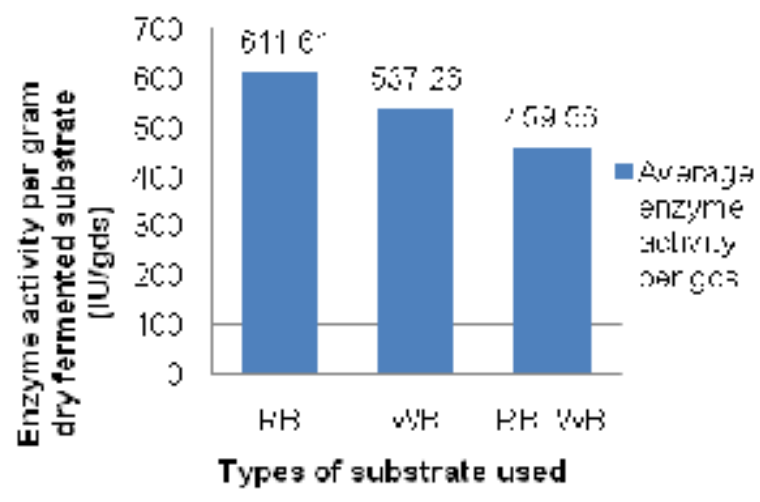

Fig. 5. Average enzyme activity per gram dry fermented substrate with respect to types of substrate

Crude enzyme extract extracted from fermented matter using rice bran as substrate gave amylase enzyme activity of $611.614 \mathrm{IU} \mathrm{gds}^{-1}$ while in case of substrate using wheat bran and mixture of rice and wheat bran in the ratio of $1: 1$ gave enzyme activity of 537.258 and $459.563 \mathrm{IU} \mathrm{gds}^{-1}$. Figure 5 reveals the enzyme activity to be highest in case of rice bran followed by wheat bran and lastly mixture of rice and wheat bran (1:1) with least enzyme activity. The result was similar to the result obtained by Alva et al. (2007), and Kumar and Duhan (2011). Highest activity in rice bran may be due to its high carbohydrate contents and suitable texture (Kumar and Duhan, 2011).

\section{Effect of strain on enzyme production}

Three different isolates Asp.19, Asp.14 and Asp.31 were inoculated separately in single type of substrate i.e. rice bran $(\mathrm{RB})$ and incubated at $30^{\circ} \mathrm{C}$ maintaining moisture content to $60 \%$ and $\mathrm{pH}$ between 6 and 7 . Crude enzyme were extracted from fermented matter after 120 hrs and assayed for amylase enzyme activity.

Amylase activity of 549.046 IU gds ${ }^{-1}$ was obtained from assay and calculation in case of substrate inoculated with Asp.19 and it was $563.687 \mathrm{IU} \mathrm{gds}^{-1}$ and $720.782 \mathrm{IU}$ gds $^{-1}$ for Asp.14 and Asp.31 respectively. The result obtained is outlined in Fig. 6.

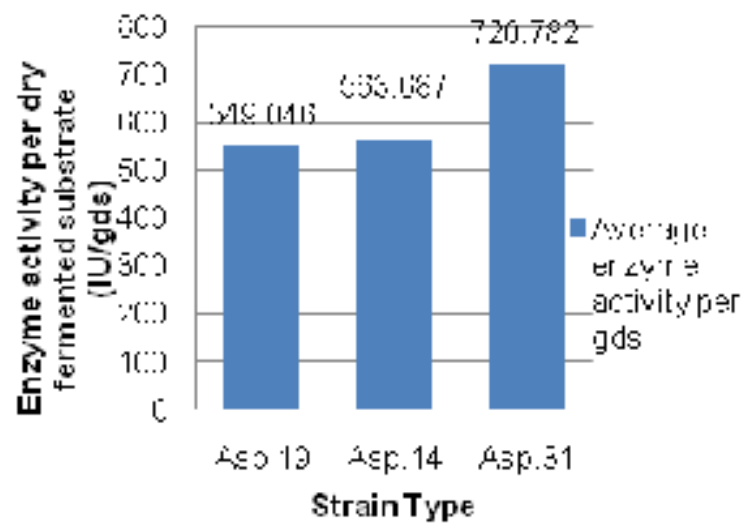

Fig. 6. Average enzyme activity per gds for different types of strains of Aspergillus spp.

Figure 6 shows that enzyme activity of crude enzyme obtained by the strain 31 was highest followed by strain 14 and strain 19 respectively in decreasing order. It clearly demonstrates the highest potency of Asp.31 to produce Amylase enzyme in comparison to Asp.14 and Asp.19. It might be because its potency to grow on solid form of substrate such as rice bran or wheat bran is high compared to others.

\section{Effect of moisture content on enzyme production}

Single strain of Aspergillus (Asp.31) was inoculated on rice bran $(\mathrm{RB})$ and incubated at $30^{\circ} \mathrm{C}$ maintaining different moisture content $(50 \%, 60 \%$ and $70 \%)$ of substrate. Crude enzyme were extracted from fermented matter after 120hrs and assayed for amylase enzyme activity. The result obtained is presented in Fig. 7. 


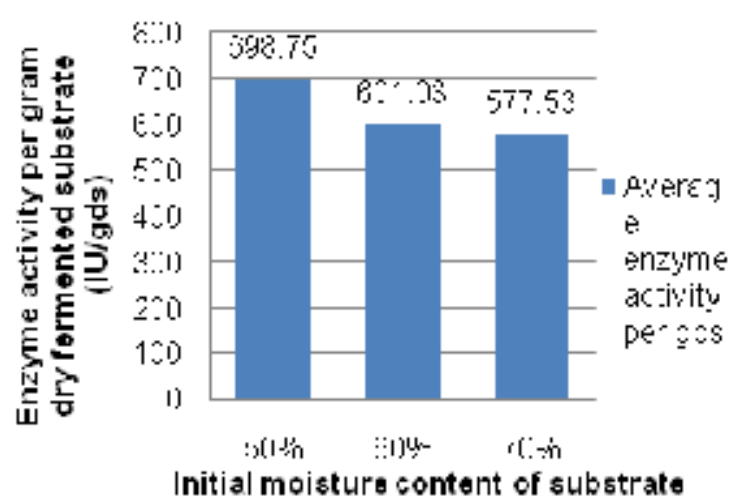

Fig. 7. Average enzyme activity per gram dry fermented substrate with respect to different initial moisture content of substrate

Crude enzyme extract possessing amylase enzyme activity of 698.749, 601.033 and $577.529 \mathrm{IU}_{\text {gds }}{ }^{-1}$ were obtained from substrate with initial moisture content of $50 \%, 60 \%$ and $70 \%$ respectively. Figure 7 reveals that enzyme activity of crude enzyme was highest in substrate with moisture content $50 \%$. Least enzyme activity was obtained at $70 \%$ moisture content of substrate. This result was found to comply with the research finding of Chutmanop et al. (2008) that was the optimum initial moisture level for highest enzyme production was about $50 \%$. According to Chutmanop et al. (2008), substrate moistened at this level afforded a high protease activity. Moisture levels much above $50 \%$ reduced enzyme production as the substrate became waterlogged. In contrast, a low moisture level reduces water activity to levels that are not conducive to supporting good fungal growth (Chutmanop et al. 2008). But from most reports of other researchers in literature, the optimum initial moisture content was found to vary. This kind of variation might be due to difference in substrate types, fungal isolates, etc. The adverse effect of catabolic repression in SSF system is related with moisture content- high moisture content leads to high catabolic repression resulting into reduced enzyme production.

Effect of temperature on enzyme production Rice bran was inoculated with single type of isolated strain Asp. 31 and incubated at $30^{\circ} \mathrm{C}$ with initial moisture content $60 \%$ with $\mathrm{pH}$ of substrate between 6 and 7 . The crude enzymes extracted from fermented matter were assayed for amylase by DNS method. Fig. 8 given below represents the result obtained.

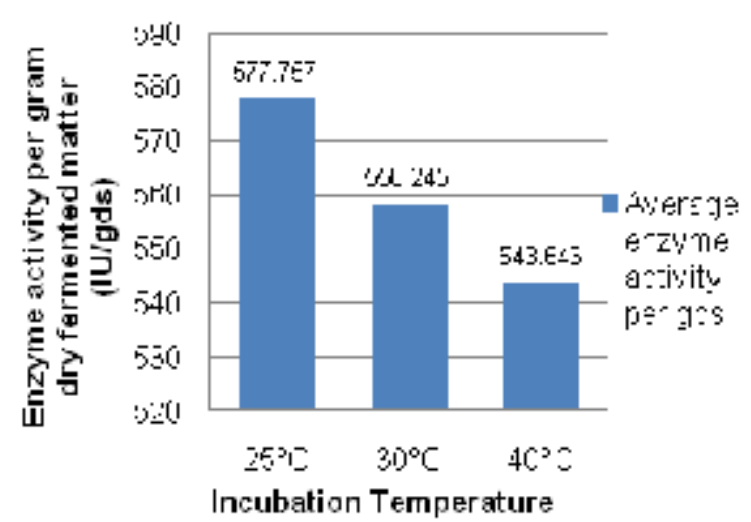

Fig. 8. Average enzyme activity per gram dry fermented substrate with respect to incubation temperature

From figure 8 it is clear that the amylase activity of crude enzyme extracted was high with 577.757 IU $\mathrm{gds}^{-1}$ in case of substrate incubated at $25^{\circ} \mathrm{C}$ and lowest at $40^{\circ} \mathrm{C}$ which was $543.646 \mathrm{IU} \mathrm{gds}^{-1}$. It was $558.245 \mathrm{IU}$ $\mathrm{gds}^{-1}$ in case of fermented matter incubated at $30^{\circ} \mathrm{C}$. The influence of temperature on amylase production is related to the growth of the organism. Hence, the optimum temperature depends on whether the culture is mesophilic or thermophilic.

\section{pH of substrate and fermentation time}

In this study initial $\mathrm{pH}$ of the substrate was found out to range between 6 and 7 . The $\mathrm{pH}$ of substrate was not changed as it requires addition of chemicals such as acid ( $\mathrm{HCl}$ ) or alkali which may degrade or deteriorate quality of amylase or difficulties might occur during purification. According to Van der Maarel et al. (2002) lowering $\mathrm{pH}$ of substrate involves the addition of acid $(\mathrm{HCl})$, which could decrease the quality of the product and hence incurs additional cost for later purification.

\section{Fermentation time}

It has been reported that maximum enzyme production by Aspergillus species was obtained after an incubation period of $120 \mathrm{~h}$. Farid \& Shata 2011, Sidkey et al. 2010, Bhattacharya et al. 2011 Zambare 2010. In the present study also incubation period was set up to 120 hrs following most research reports.

\section{Purification of amylase enzyme}

Organic solvents cause precipitation of protein largely by changing the solubility of the protein with water. The reaction is carried out at low temperature to 
prevent denaturation. Crude enzyme was further purified by acetone precipitation at different percentage and salting out method by use of ammonium sulfate of different concentration. Purified forms of amylase obtained were assayed for amylase activity. The data are presented in Table 1.

\section{Table 1. Purification of amylase enzyme}

\begin{tabular}{l|l}
\hline Test sample & $\begin{array}{l}\text { Enzyme activity } \\
\text { (IU ml }^{-1} \text { ) }\end{array}$ \\
\hline Crude enzyme & 982.4561 \\
35\% acetone & 5380.12 \\
50\% acetone & 11228.07 \\
30\% ammonium sulfate & 6081.87 \\
\hline
\end{tabular}

The use of $35 \%$ of acetone gave enzyme activity of $5380 \mathrm{IU} \mathrm{ml}^{-1}$ and 50\% acetone gave $11228.07 \mathrm{IU} \mathrm{ml}^{-1}$ amylase enzyme activities. Amylase enzyme activity was found to be gradually increasing by the use of acetone at $30 \%$ and $50 \%$ concentration. Amylase enzyme activity of crude enzyme was $982.4561 \mathrm{IU} \mathrm{ml}^{-}$ ${ }^{1}$. Enzyme with $6081.87 \mathrm{IU} \mathrm{ml}^{-1}$ amylase enzyme activity was obtained after $30 \%$ ammonium sulfate precipitation. This decrease in enzyme activity might be due to loss in amylase activity during enzyme purification and also may be because ammonium sulfate salt was not of enzyme grade

From the present study, starch hydrolysis test and DNS test Asp.31 was identified to be the most potent fungal isolate. Rice bran was found to be most suitable substrate and Asp.31 to be most potent isolate while $50 \%$ moisture content and $25^{\circ} \mathrm{C}$ temperature were found to be optimum for maximum amylase production. The enzyme was purified by acetone and ammonium sulfate precipitation. Amylase activity was found to increase after purification of enzyme by acetone and ammonium sulfate.

\section{Acknowledgements}

Authors gratefully acknowledge the Department of Microbiology (Food), National College and its staff. Furthermore, the contribution of Dr. Madhav Prasad Baral, the Campus chief, is duly acknowledged.

\section{References}

Alva, S, J. Anupama, J. Savla, Y.Y. Chiu, P. Vyshali, M. Shruti, B.S. Yogeetha, D. Bhavya , J. Purvi, K. Ruchi, B.S. Kumudini and K.N. Varalakshmi. 2007.
Production and characterization of fungal amylase enzyme isolated from Aspergillus spp. JGI 12 in solid state culture. Afr. J. Biotech. 6 (5): 576-81.

Aneja, K.R. 2008. Experiments in microbiology, plant pathology and biotechnology. $4^{\text {th }} \mathrm{ed}^{\mathrm{n}}$. New Age International (P) Limited Publishers, Ansari Road, Daryaganj, New Delhi.

Ashraf, M.H. 2004. Studies on the biogenesis of alpha amylase by a mutant strain of Bacillus sp. Ph.D. Dessertation. Department of Botany, University of the Punjab, Lahore, Pakistan.

Bhattacharya, S, S. Bhardwaj, A. Das and S. Anand. 2011. Utilization of sugarcane bagasse for solid- state fermentation and characterization of á- amylase from Aspergillus flavus isolated from Muthupettai Mangrove, Tamil Nadu, India. Aust. J. Basic and Applied Sci. 5(12): 1012-1022.

Bothast, R. J. and D. I. Fennell. 1974. A medium for rapid identification and enumeration of Aspergillus flavus and related organisms. Mycologia 66:365-369.

Cherry, H.M., M.T. Hossain, and M.N. Anwar. 2004. Extracellular glucoamylase from the isolate Aspergillus fumigatus. Pakistan J. Biol. Sci. 7(11): 1988-1992.

Chutmanop, J., S. Chuichulcherm, Y. Chisti and P. Srinophakun. 2008. Protease production by Aspergillus oryzae in solid-state fermentation using agroindustrial substrates. J. Chem Technol. Biotechnol. 83: 1012-1018.

de Souza, P.M. and P. de Oliveira e Magalhães. 2010. Application of microbial á-amylase in industry - A review. J. Microbiol. 41: 850-861.

Elbashiti, T., A. Fayyad and A. Elkichaoui. 2010. Isolation and identification of Aspergillus oryzae and the production of soy sauce with new aroma. Pakit $J$. Nutr. 9 (12): 1171-1175.

Ellaiah, P., K. Adinarayana, Y. Bhavani, P. Padmaja and B. Srinivasulu. 2002. Optimization of process parameters for glucoamylase production under solid state fermentation by newly isolated Aspergillus species. Process Biochem. 38: 615-620.

Farid, M.A.F. and H.M.A.H. Shata. 2011. Amylase production from Aspergillus oryzae LS1 by solid-state fermentation and its use for the hydrolysis of wheat flour. Iranian J. Biotechnol. 9(4): 267-274.

Helrich, K. 1990. Official methods of analysis of the association of official analytical chemists AOAC, Inc. 2nd ed.. Suite 400, 2200 Wilson Boulevard, Arlington, Virginia 22201, USA.

Khadka, N.M. 2009. Study of amylase enzyme of Streptococcus spp. isolated from solid waste. M.Sc. Dissertation. Central Department of Microbiology, Tribhuvan University, Kathmandu, Nepal.

Kumar, A. and J.S. Duhan. 2011. Production and characterization of amylase enzyme isolated from Aspergillus niger mtcc-104 employing solid state fermentation. Int. J. Pharma. and Bio. Sci. 2: 250-258. 
Bina Gautam et al/Optimization of cultural conditions for......

Maharjan, N.D. 2007. Biogenesis of Aspergillus flavus isolated from raw peanut samples and study on their growth suppression using chemical agents. M.Sc. Dissertation. Department of Microbiology, National College, Khusibu, Kathmandu, Nepal.

Miller, G.L. 1972. Use of dinitrosalicylic acid reagent for determination of reducing sugar. Analytical Chem. 31: 426 .

Morya, V. and D. Yadav. 2009. Isolation and screening of different isolates of Aspergillus for amylases production. The Internet J. Microbiol. 7(1).

Patel, A.K., K.M. Nampoothiri, S. Ramachandran, G. Szakacs and A. Pandey. 2005. Partial purification and characterization of á-amylase produced by Aspergillus oryzae using spent-brewing grains. Indian $J$. Biotechnol. 4: 336-341.

Rahardjo, Y.S.P. 2005. Fungal mats in solid-state fermentation. $\mathrm{PhD}$ thesis. Wageningen University, Wageningen, The Netherlands.

Salkin, I.F. and M. A. Gordon. 1975. Evaluation of Aspergillus differential medium. J. Clinical Microbiol. 2(1): 74-75.

Sidkey, N.M., Maair Abo-Shadi, Al-Mutrafy A.M., S. Fatma and N. Al-Reheily. 2010. Screening of microorganisms isolated from some enviro-agro-industrial wastes in Saudi Arabia for amylase production. J. American Sci. 6(10): 926-939.
Singh, R.K., S. Kumar and S. Kumar. 2009. Production of áamylase from agricultural byproducts by Humicola lanuginosa in solid state fermentation. Current Trends in Biotechnology and Pharmacy. 3(2): 172180.

Sivaramakrishnan, S., D. Gangadharan, K.M. Nampoothiri, C.R. Soccal and A. Pandey. 2007. Alpha amylase production by Aspergillus oryzae employing solid state fermentation. J. Scientific and Industrial Research. 66: 621-626.

Teka, M. 2006. Amylases of potential industrial application from microbial sources. M.Sc. dissertation. Department of Applied Microbiology, School of Graduate Studies of Addis Ababa University, Addis Ababa, Ethiopia.

Van der Maarel, M.J.E.C., B.Van der Veen, J.C.M. Utdehaag, H. Leenhuis and L. Dijkhuizen. 2002. Properties and applications of starch converting enzymes of the alpha amylase family. J. Biotechnol. 94: 137-155.

Wang, N.S. Glucose assay by dinitrosalicylic colorimetric method. http://www.eng.umd.edu/ nsw/ench485/ lab4a.htm. (Accessed on 14 May 2011).

http://en.wikipedia.org/wiki/Michaelis-Menten. (Accessed on 5 February 2012).

Zambare, V. 2010. Solid state fermentation of Aspergillus oryzae for glucoamylase production on agroresidues. Int. J. Life Sci. 4: 16-25. 
Nepal Journal of Science and Technology Vol. 14, No. 1 (2013) 67-74 